\title{
Physiotherapy in primary dysmenorrhea: literature review*
}

\author{
Fisioterapia na dismenorreia primária: revisão de literatura \\ Laís Rodrigues Gerzson ${ }^{1}$, Juliana Falcão Padilha², Melissa Medeiros Braz ${ }^{3}$, Andriele Gasparetto ${ }^{4}$ \\ ${ }^{*}$ Received from the University Center Fransciscano, Santa Maria, RS, Brazil.
}

\section{ABSTRACT}

BACKGROUND AND OBJECTIVES: Dysmenorrhea is a word derived from the Greek language and means difficult menstrual cycle. It may be classified as primary, leading to poorer quality of life indices of several women. This study aimed at investigating, by means of literature review, the efficacy and accuracy of existing therapies for primary dysmenorrhea, specifically in Physiotherapy.

CONTENTS: Narrative literature review by querying electronic databases Medline, Scielo, Lilacs, Cochrane library, PEDro and Pubmed), where articles were selected and analyzed from August 2013 to February 2014. For data collection, materials from 2005 to current literature were included using the following keywords: "dysmenorrhea", "physiotherapy" and their Portuguese equivalent "dismenorreia" and "fisioterapia", combining them with the operators AND and OR.

CONCLUSION: Studies were found describing the use of thermotherapy, cryotherapy, transcutaneous electric nerve stimulation and connective tissue massage, Pilates and acupuncture with improvement of such women's symptoms. However, it is clear the need for studies regarding physiotherapeutic maneuvers with further methodological rigor.

Keywords: Dysmenorrhea, Physiotherapy, Woman's health.

\section{RESUMO}

JUSTIFICATIVA E OBJETIVOS: Dismenorreia é uma palavra derivada do grego e significa fluxo menstrual difícil. Pode ser classificada como primária, causando diminuição dos índices de qualidade de vida de muitas mulheres. O objetivo deste estudo

1. University Center Franciscano, Santa Maria, RS, Brazil.

2. University of the State of Santa Catarina, Florianópolis, SC, Brasil

3. Federal University of Santa Maria, Santa Maria, RS, Brazil.

4. Tocantinense Institute Presidente Antonio Carlos Porto Ltda., Teaching and Research Institute Objectivo, Research Group for Health Promotion and Technologies Applied to Physiotherapy, Tocantins, TO, Brazil.

Submitted in May 06, 2014.

Accepted for publication in September 22, 2014.

Conflict of interests: none.

Correspondence to

Melissa Medeiros Braz

Rua dos Andradas, 602/702 - Centro

97010-030 Santa Maria, RS, Brasil.

E-mail: melissabraz@hotmail.com

( ) Sociedade Brasileira para o Estudo da Dor foi investigar, por meio de uma revisão bibliográfica, a eficácia e acurácia de tratamentos existentes para dismenorreia primária, especificamente na Fisioterapia.

CONTEÚDO: Revisão bibliográfica narrativa, por meio da busca em bases de dados eletrônicas (Medline, Scielo, Lilacs, biblioteca Cochrane, PEDro e Pubmed), com artigos selecionados e analisados durante o periodo de agosto de 2013 à fevereiro de 2014. Para a coleta foram incluídos materiais de 2005 até a literatura atual com os seguintes descritores: "dysmenorrhea", "physiotherapy" e seus equivalentes em português "dismenorreia" e "fisioterapia" combinando-os com os operadores "AND" e "OR". CONCLUSÄO: Encontraram-se trabalhos que descreveram a utilizaçáo dos recursos da termoterapia, crioterapia, eletroestimulação elétrica neural transcutânea e massagem do tecido conjuntivo, Pilates e acupuntura, com resultados que apresentam melhoras na sintomatologia dessas mulheres. No entanto, tornase evidente a necessidade do desenvolvimento de estudos referentes às manobras fisioterapêuticas com maior rigor metodológico. Descritores: Dismenorreia, Fisioterapia, Saúde da mulher.

\section{INTRODUCTION}

Menstruation is a periodic and temporary genital bleeding, lasting from menarche to menopause ${ }^{1}$. In addition, it is characteristic of primates and is defined as cyclic uterine hemorrhage dependent on endometrial disintegration and exfoliation, which occurs approximately in a normal cycle of 21 to 45 days, with 2 to 6 days of flow and mean blood loss of 20 to $60 \mathrm{~mL}$, in general lasting 40 years $^{2}$.

Dysmenorrhea, on the other hand, is pelvic or lower abdominal cyclic or recurrent pain, associated to menstruation. It is the most common gynecological complaint among young women, with prevalence between 43 and $93 \%{ }^{3}$. According to symptoms intensity, it is also major cause for school or work absenteeism ${ }^{4}$. The word dysmenorrhea comes from the Greek language and means difficult menstrual flow, being one of the most frequent gynecological affections with higher or lower intensity during menstrual cycle 5 .

According to its clinical presentation, primary dysmenorrhea (PD) is characterized by lack of visible structural abnormality or any gynecological pelvic disease and is the most commonly diagnosed type among teenagers ${ }^{3}$. Functional dysmenorrhea coincides with the onset of regular ovulation cycles, which is more frequent approximately two years after menarche ${ }^{3}$. Major symptom is lower abdominal or lumbar region pain, followed by other symptoms such as nausea, vomiting, headache and diar- 
rhea $^{6}$. Pain may decrease after puerperal gravid cycle and, due to this, it is suggested that in such patients uterine isthmus is hypertonic, resulting in temporary retention of menstrual flow residues (which causes pressure in this highly innervated area). Approximately 50 to $70 \%$ of women have dysmenorrhea symptoms in some moment of life, being that approximately $10 \%$ become unable to perform their routine activities ${ }^{3}$.

Many therapies are proposed for dysmenorrhea and include the use of non-steroid anti-inflammatory drugs (NSAIDs), oral contraceptives, vitamins and tocolytic agents ${ }^{1} \mathrm{~A}$ different treatment option is the practice of physical activities, for improving pelvic and extra-pelvic organs functioning by adjusting metabolism, hydroelectrolytic balance, hemodynamic conditions and blood flow, thus promoting a phenomenon known as analgesia by physical exercise which, by means of endogenous mechanisms and endogenous opioids release, raises pain threshold ${ }^{7,8}$.

Physiotherapy has a diversity of therapeutic resources aiming at decreasing or eliminating pain in a practical and economic way, and may even undo negative associations surrounding this period, promoting better quality of life ${ }^{9}$ by means of some analgesic modalities, such as therapeutic exercises (kinesiotherapy), electrotherapy and therapeutic massage ${ }^{10}$.

In light of the above, this study aimed at investigating, by means of literature review, the efficacy and accuracy of existing therapies for $\mathrm{PD}$, specifically in physiotherapy.

\section{CONTENTS}

A narrative literature review was carried out, where studies were identified by querying electronic databases Medline, Scielo, Lilacs, Cochrane, PEDro and Pubmed from August 2013 to Feb- ruary 2014. Materials from 2005 until what is presented by current literature were selected for analysis.

Articles were located using the following terms: "dysmenorrhea", "physiotherapy", and their Portuguese equivalents "dismenorreia" and "fisioterapia", combining with operators "AND" and "OR". Inclusion criteria were: (1) articles with complete text; (2) written in Portuguese or in English; (3) published between 2005 and 2014; (4) addressing physiotherapy and/or other complementary therapies to treat dysmenorrhea. There have been no restrictions to the sample to maximize study results. Excluded from the study were: (1) monographs; (2) review articles; (3) events proceedings; (4) dissertations and theses; (5) pharmacological studies or those addressing just this aspect in dysmenorrhea; (6) studies addressing secondary dysmenorrhea; (7) studies outside the studied period and (8) animal studies.

The search has resulted in 210 articles (189 in Pubmed, 7 in Cochrane, 4 in Scielo, 10 in Lilacs, zero in PEDro, zero in Medline). After reading them, 186 articles were excluded for not contemplating the stipulated period or the proposed subject and 10 were repeated articles, remaining 15 articles, the major results of which are shown in table 1.

In general, the review carried out by the practice of Traditional Chinese Medicine (TCM) therapy, acupressure and acupuncture, has shown improvement in dysmenorrhea pain symptoms. Remaining resources, such as connective tissue massage, abdominal meridian (Hyongrak) massage, transcutaneous electric nerve stimulation (TENS), Pilates and belly dance, have shown how effective they are for dysmenorrhea patients' pain.

Table 1. Description of selected texts

\begin{tabular}{|c|c|c|c|c|}
\hline Authors & $\begin{array}{l}\text { Types of study } \\
\text { and } n\end{array}$ & Objectives & Results & Conclusion \\
\hline $\begin{array}{l}\text { Kim, Jo e } \\
\text { Hwang }^{11}\end{array}$ & $\begin{array}{l}\text { Case con- } \\
\text { trolled. } 85 \\
\text { women (42 ex- } \\
\text { perimental and } \\
43 \text { control) }\end{array}$ & $\begin{array}{l}\text { To examine the ef- } \\
\text { fects of massage in } \\
\text { the abdominal me- } \\
\text { ridian (Kyongrak) } \\
\text { on dysmenorrhea. }\end{array}$ & $\begin{array}{l}\text { Menstrual cramps symptoms in the experimental } \\
\text { group were significantly lower after abdominal merid- } \\
\text { ian massage as compared to control group }(p<0.001)\end{array}$ & $\begin{array}{l}\text { Massage on abdominal } \\
\text { meridian (Kyongrak) was ef- } \\
\text { fective to relieve menstrual } \\
\text { cramps. It is suggested that } \\
\text { the technique might be an } \\
\text { alternative to treat dysmen- } \\
\text { orrhea. }\end{array}$ \\
\hline $\begin{array}{l}\text { Schiøtz, Jettes- } \\
\text { tad \& Al-Heeti }{ }^{12}\end{array}$ & $\begin{array}{l}\text { Prospective. } \\
21 \text { women }\end{array}$ & $\begin{array}{l}\text { To observe the ef- } \\
\text { fects of high fre- } \\
\text { quency TENS on } \\
\text { dysmenorrhea. }\end{array}$ & $\begin{array}{l}\text { There has been decrease in mean pain score in wom- } \\
\text { en treated with TENS ( } p=0.0009) \text {. Simultaneous use } \\
\text { of analgesic tablets was also significantly decreased } \\
(\mathrm{p}=0.03) \text { and } 7 \text { women stopped using analgesics dur- } \\
\text { ing the use of the device }(\mathrm{p}=0.02) \text {. There have been no } \\
\text { adverse effects. After } 6 \text { to } 8 \text { months, } 14 \text { women were } \\
\text { regularly using the device. }\end{array}$ & $\begin{array}{l}\text { TENS is an alternative to } \\
\text { treat dysmenorrhea. }\end{array}$ \\
\hline Tugay et al. ${ }^{13}$ & $\begin{array}{l}\text { Prospective, } \\
\text { randomized, } \\
\text { controlled. } \\
34 \text { women }\end{array}$ & $\begin{array}{l}\text { To compare the } \\
\text { effectiveness of } \\
\text { TENS and interfer- } \\
\text { ential current on PD } \\
\text { soon after applica- } \\
\text { tion, } 8 \text { and } 24 \text { hours } \\
\text { later. }\end{array}$ & $\begin{array}{l}\text { Intensity of evaluated parameters (menstrual pain, re- } \\
\text { ferred pain in lower limbs and low back pain) were de- } \\
\text { creased soon after applications in both groups (TENS } \\
\text { and interferential) }(p<0.05) \text {. One may say that there } \\
\text { has been no superiority between methods }(p>0.05)\end{array}$ & $\begin{array}{l}\text { Both TENS and interferen- } \\
\text { tial current seem to be ef- } \\
\text { fective to treat PD. }\end{array}$ \\
\hline
\end{tabular}


Table 1. Description of selected texts - continuation

\begin{tabular}{|c|c|c|c|}
\hline Guo \& Meng ${ }^{14}$ & $\begin{array}{l}\text { Case con- } \\
\text { trolled. } 60 \\
\text { women divid- } \\
\text { ed in } 30 \text { con- } \\
\text { trol group and } \\
30 \text { treatment. }\end{array}$ & $\begin{array}{l}\text { To observe thera- } \\
\text { peutic effects of } \\
\text { acupuncture com- } \\
\text { bined with Tuiná } \\
\text { (TUI-NÁ) on PD } \\
\text { symptoms. }\end{array}$ & $\begin{array}{l}\text { From } 30 \text { treatment group cases, } 17 \text { were cured, } 11 \\
\text { have improved and } 2 \text { have failed, with total effective } \\
\text { rate of } 93.3 \% \text {. From } 30 \text { control group cases, } 9 \text { were } \\
\text { cured, } 13 \text { have improved and } 8 \text { have failed, with total } \\
\text { effective rate of } 73.3 \% \text {. Comparison of both groups } \\
\text { total effective rate has shown significant difference } \\
\left(x^{2}=4.32, p<0.05\right) \text {, suggesting that therapeutic effect } \\
\text { on treatment group was superior as compared to con- } \\
\text { trol group. }\end{array}$ \\
\hline Witt et al. ${ }^{15}$ & $\begin{array}{l}\text { R a } \mathrm{n} \text { d o m - } \\
\text { ized, clinical } \\
\text { trial plus non- } \\
\text { randomized } \\
\text { cohort. } 649 \\
\text { women being } \\
201 \text { random- } \\
\text { ized. }\end{array}$ & $\begin{array}{l}\text { To investigate } \\
\text { clinical effective- } \\
\text { ness and cost- } \\
\text { effectiveness rate } \\
\text { of acupuncture in } \\
\text { dysmenorrhea pa- } \\
\text { tients. }\end{array}$ & $\begin{array}{l}\text { Three months later, mean pain intensity was lower } \\
\text { with acupuncture as compared to control group. Acu- } \\
\text { puncture group had better QL and higher cost. }\end{array}$ \\
\hline
\end{tabular}

Araújo, Leitão \& Transversal. To compare cryoVentura $^{16}$ 20 women

Bazarganipour et al. ${ }^{17}$

Lin et al. ${ }^{18}$

Reis, Hardy \& Sousa $^{19}$

Pilot, observa- To evaluate the eftional and co- fects of connective hort study. 75 women.

Case report. 1 Describes the obwoman therapy and thermotherapy to control PD pain.

Double blind, To examine whethrandomized. er the application 194 women of a simple acupuncture protocol to the Taichong point is effective to relieve dysmenorrhea pain. servation of painful dysmenorrhea and its associated symptoms relief in a PD patient after treatment with CMAT.

Pain intensity was significantly lower in the group treated with cryotherapy. Patients submitted to treatment with cold had higher satisfaction as compared to those treated with heat.

The difference in dysmenorrhea severity between groups was not significant in the first cycle, but was significant in the fourth cycle $(U=2377.00, p<0.001)$, and it has significantly decreased in the study group $(p<0.05)$.

CMAT was performed once in the second day of the first (partial treatment) and fourth menstrual cycle (complete treatment). Pain was immediately resolved after partial CMAT treatment during the first menstrual cycle, but has reappeared 20 minutes later. Satisfactory results were obtained during the fourth menstrual cycle after complete CMAT treatment, which was also forwarded to the next session (fifth menstrual period). However, dysmenorrhea symptoms have recurred 2 months after treatment (sixth menstrual period).

Pain score has significantly decreased after the first month of treatment. Percentage of volunteers needing painkillers and reporting systemic symptoms has decreased along treatment, but there has been no correlation between the number of massages and pain scores in the multivariate analysis. therapeutic nonpharmacological proposal for PD.
Acupuncture combined with Tuiná (TUI-NÁ) has good perspectives to treat PB.

Acupuncture in dysmenorrhea patients was associated to better QL as compared to control group.

In PD patients, cryotherapy was more effective than heat to decrease pain intensity.

The application of a simple pressure protocol for acupoint Taichong is an effective and low cost way to decrease intensity of dysmenorrhea symptoms.

This case report indicates that CMAT treatment may be effective to relieve dysmenorrhea-associated symptoms. The transition effect could suggest that there is potential to produce a long-lasting effect for dysmenorrhea.

Connective tissue massage may decrease menstrual pain, but the type of study does not allow ruling out placebo effect. Results justify a randomized clinical trial to confirm or not such effect.

There have been significant decrease in menstrual pain scores, pulsatility index, resistance index and systolic and diastolic peak ratio in the SP6 treatment group five minutes after treatment. As compared to control group GB39, SP6 treatment group patients had significant decrease in changes in menstrual pain scores, pulsatility index, resistance index and systolic and diastolic peak ratio five minutes after treatment. There have been no significant changes in menstrual pain scores, pulsatility index, resistance index and systolic and diastolic peak ratio before and after treatment in the GB39 control group ( $p>0.05)$.
This study suggests that needling at SP6 may immediately improve uterine arterial blood flow in PD patients, while GB39 does not have such effects. 
Table 1. Description of selected texts - continuation

\begin{tabular}{|c|c|c|c|c|}
\hline Liu et al. ${ }^{21}$ & $\begin{array}{l}\text { Randomized } \\
\text { study. } \\
194 \text { women } \\
\text { with PD }\end{array}$ & $\begin{array}{l}\text { To evaluate the ef- } \\
\text { fectiveness of a } \\
\text { single acupuncture } \\
\text { point to treat PD as } \\
\text { compared to pla- } \\
\text { cebo acupuncture } \\
\text { and no acupunc- } \\
\text { ture. } \\
\text { Acupoint group } \\
\text { ( } \mathrm{n}=50), \text { unrelated } \\
\text { acupoint group } \\
(\mathrm{n}=50), \text { placebo } \\
\text { group ( } \mathrm{n}=46 \text { ), no } \\
\text { acupuncture group } \\
\text { ( } \mathrm{n}=48) .\end{array}$ & $\begin{array}{l}\text { Primary outcome, primary VAS scores comparison } \\
\text { with regard to treatment used has shown that patients } \\
\text { receiving acupuncture, those of unrelated acupoint } \\
\text { group and of the placebo group have shown signifi- } \\
\text { cant improvements as compared to the group receiv- } \\
\text { ing no acupuncture. There have been no significant } \\
\text { differences among four groups with regard to second- } \\
\text { ary outcomes. }\end{array}$ & $\begin{array}{l}\text { Acupuncture was beneficial } \\
\text { to relieve dysmenorrhea } \\
\text { pain as compared to the } \\
\text { group with no acupuncture; } \\
\text { however, and significantly, } \\
\text { there have been no dif- } \\
\text { ferences among acupoint } \\
\text { group, unrelated acupoint } \\
\text { group and placebo group. }\end{array}$ \\
\hline $\begin{array}{l}\text { M i r b a g h e r- } \\
\text { Ajorpaz, Adib- } \\
\text { Hajbaghery \& } \\
\text { Mosaebi22 }\end{array}$ & $\begin{array}{l}\text { Controlled, } \\
\text { randomized. } \\
30 \text { young stu- } \\
\text { dents }\end{array}$ & $\begin{array}{l}\text { To evaluate the ef- } \\
\text { fect of acupressure } \\
\text { on SP6 point on } \\
\text { PD. }\end{array}$ & $\begin{array}{l}\text { Acupressure was applied to point SP6 in the treat- } \\
\text { ment group and a mild touch at acupoint SP6 was } \\
\text { applied to control group. There have been significant } \\
\text { differences in dysmenorrhea scores between groups } \\
\text { immediately after and also } 3 \text { hours after treatment. }\end{array}$ & $\begin{array}{l}\text { Acupressure on meridian } \\
\text { SP6 might be a non-inva- } \\
\text { sive nursing intervention to } \\
\text { relieve PD and its effects } \\
\text { last for } 3 \text { hours after treat- } \\
\text { ment. }\end{array}$ \\
\hline Araújo et al. ${ }^{23}$ & $\begin{array}{l}\text { Descriptive, } \\
\text { experimental, } \\
\text { with longitu- } \\
\text { dinal charac- } \\
\text { teristic and } \\
\text { quantitative } \\
\text { approach. } 10 \\
\text { women. }\end{array}$ & $\begin{array}{l}\text { To compare pain } \\
\text { in PD women be- } \\
\text { fore and after being } \\
\text { submitted to the Pi- } \\
\text { lates method. }\end{array}$ & $\begin{array}{l}\text { Menstrual pain before treatment was } 7.89 \pm 1.96 \text { and } \\
\text { after treatment } 2.56 \pm 0.56 \text { with } p<0.001 \text {, showing sig- } \\
\text { nificant difference before and after Pilates method } \\
\text { treatment. In evaluating pain with McGill Pain ques- } \\
\text { tionnaire, there has been significant decrease in all } \\
\text { components when comparing values before and after } \\
\text { treatment: sensory }(p<0.001) \text {, affective }(p<0.05) \text {, eval- } \\
\text { uative }(p<0.001) \text { and miscellaneous }(p<0.001) \text {. }\end{array}$ & $\begin{array}{l}\text { Pilates method as physi- } \\
\text { cal activity practice has } \\
\text { improved PD-associated } \\
\text { symptoms, decreasing pa- } \\
\text { tients' pain, and might be a } \\
\text { promising non-pharmaco- } \\
\text { logical alternative. }\end{array}$ \\
\hline Nascimento ${ }^{24}$ & $\begin{array}{l}\text { Descriptive, } \\
\text { quasi-exper- } \\
\text { imental with } \\
\text { quantitative } \\
\text { approach. } 8 \\
\text { beginner belly } \\
\text { dance learn- } \\
\text { ers. }\end{array}$ & $\begin{array}{l}\text { To evaluate thera- } \\
\text { peutic effect of bel- } \\
\text { ly dance in women } \\
\text { with complaints } \\
\text { suggestive of PD. }\end{array}$ & $\begin{array}{l}\text { With regard to PD complaints, VAS has recorded sig- } \\
\text { nificant decrease. At the end of the fifth evaluation, it } \\
\text { was observed that belly dance has therapeutic effect } \\
\text { to decrease PD complaints. }\end{array}$ & $\begin{array}{l}\text { Belly dance had positive } \\
\text { effects on decreasing men- } \\
\text { strual cramps, being a non- } \\
\text { pharmacological option for } \\
\text { these women. }\end{array}$ \\
\hline Yeh et al. ${ }^{25}$ & $\begin{array}{l}\text { Simple, blind, } \\
\text { placebo con- } \\
\text { trolled. } 113 \\
\text { participants }\end{array}$ & $\begin{array}{l}\text { To evaluate the ef- } \\
\text { fects of auricular } \\
\text { acupuncture on } \\
\text { menstrual pain and } \\
\text { distress on teenag- } \\
\text { ers with dysmenor- } \\
\text { rhea. }\end{array}$ & $\begin{array}{l}\text { Differences between groups were found in VAS and } \\
\text { MDQ after interventions. Differences within group } \\
\text { were found in changes of VAS, SF-MPQ and MDQ } \\
\text { scores during interventions for both groups. }\end{array}$ & $\begin{array}{l}\text { Auricular acupuncture re- } \\
\text { lieves teenagers' menstrual } \\
\text { pain and distress and may } \\
\text { be a basis for the use of au- } \\
\text { ricular acupuncture to treat } \\
\text { dysmenorrhea. There has } \\
\text { been pain decrease with } \\
\text { placebo as well as with the } \\
\text { real acupuncture point, but } \\
\text { the latter was significantly } \\
\text { better. Placebo acupunc- } \\
\text { ture point cannot be used } \\
\text { as control for auricular } \\
\text { acupuncture point and for } \\
\text { qualitative evaluation of } \\
\text { dysmenorrhea. }\end{array}$ \\
\hline
\end{tabular}

TENS: transcutaneous electric nerve stimulation; QL: quality of life; PD: primary dysmenorrhea; CMAT: collateral meridian acupressure therapy; SF-MPQ: Short-Form McGill Pain Questionnaire; MDQ: Menstrual Distress Questionnaire.

Currently, in gynecology, studies have discussed therapeutic ways to minimize discomfort, especially in case of primary dysmenorrhea, however, when it comes to treatment, analgesics are the first line to manage primary dysmenorrhea ${ }^{26}$. They act by decreasing cyclooxygenase pathway activity, inhibiting prostaglandin synthesis. There are studies showing that NSAIDs improve
17 to $95 \%$ of women's complaints, being their gastrointestinal side-effects in general tolerable, but should be avoided in women with risk to developing ulcer ${ }^{27}$. However, currently NSAIDs only last during pain crisis, providing immediate pain relief with palliative and emergency connotation, thus crisis may be repeated at every menstruation ${ }^{28}$. 
However, some women cannot make use of this conventional therapy and others do not respond (10 to 20\% ${ }^{29}$. Added to this, Brazilian women self-medicate, using homemade or pharmacological practices, following prescription of unqualified people, such as neighbors, friends or even written, spoken or broadcasted media ${ }^{30}$, which may generate a public health problem.

However, other therapies may be used or be associated to drugs, such as Physiotherapy, which is showing satisfactory results among women with this disorder. There are physiotherapeutic resources to decrease severity of primary dysmenorrhea symptoms or even to eliminate pain. Among them, there are: thermotherapy and cryotherapy; abdominal meridian (Kyongrak) massage; kinesiotherapy; connective tissue massage (CTM); TENS; interferential current; acupuncture; acupressure; collateral meridian acupressure therapy (CMAT); Pilates and auricular acupuncture.

Pilates has been effective for primary dysmenorrhea, as shown by a study by Araujo et al. ${ }^{23}$ with 10 women aged between 18 and 30 years, submitted to the protocol of 16 exercises based on the Pilates method, with ball and on the ground, aimed at the pelvic region. Authors have observed significant decrease in pain intensity reported by participants due to increased blood flow, correction of muscle and postural imbalances and recovery of body and mind vitality ${ }^{31}$.

Thermotherapy was also other recurrent treatment for this disorder. Cold and heat are resources able to decrease or eliminate pain in a practical and economic way, through physiological effects they may produce in the organism when directly applied to the body ${ }^{16}$. The speed of the effect of cold on pain suggests that lower temperature may act as another sensory stimulation on pain behavior mechanism, and since cold stimulations are very intense, they may lead to endorphins and enchephalins release. As skin temperature lowers, stimulation to produce heat intensifies the mechanism ${ }^{31}$.

TENS is one of the simplest electrotherapy modalities, being a valuable physical resource to relieve pain induced both by acute and chronic injuries ${ }^{32}$. This is an alternative, noninvasive, nontoxic method with the major advantage of not having side-effects ${ }^{33}$. Oliveira et al..$^{34}$ have evaluated high and low frequency TENS effect in women with moderate to severe primary dysmenorrhea. Menstrual pain was measured by the Numeric Rating Scale (NRS), varying from zero to 10 , before and soon after the intervention in all groups. At initial evaluation, groups were homogeneous, without significant pain score difference $(\mathrm{p}=0.875)$. Intragroup analysis of NRS scale data before and after TENS, has shown that high frequency TENS (HFT) and low frequency TENS (LFT) groups had significant difference $(\mathrm{p}=0.038 ; \mathrm{p}=0.008)$. However the TENS placebo (TP) group had no difference ( $\mathrm{p}=0.346)$. Intergroup analysis has not found significant difference among groups when comparing the first and the second evaluation $(\mathrm{p}=0.267)$. So, HFT and LFT were effective to relieve pain, being easy to apply, comfortable and with no adverse effects.

Therapeutic proposals which are being increasingly used by qualified professional derive from TCM, such as acupunc- ture, acupressure and auricular acupuncture. Studies ${ }^{21,25}$ have shown improved pain in women suffering from primary dysmenorrhea. The study by $\mathrm{Yu}$ et al. ${ }^{20}$ reports that immediate acupuncture effect on Sanyinjiao point (SP6) provides immediate menstrual flow improvement. A study by Mirbagher-Ajorpaz, Adib-Hajbaghery \& Mosaebi ${ }^{22}$, using a different theory (acupressure at point SP6), has also observed positive pain improvement results.

Another aspect to manage this disease, belly dance, has shown to be positive to relieve pain. This is possibly related to the similarity with kinesiotherapy exercises such as: pelvic anterior and posterior tilt, forward and backward rotations, lateral tilts, pelvic elevation and depression, in addition to stretching and breathing exercises. Such exercises massage internal organs, thus improving blood circulation and metabolism regulation leading to improved health and benefiting legs and internal organs ${ }^{24}$.

One should also mention connective tissue massage, which suggests menstrual pain decrease because it is a spontaneous stimulation aiming at activating connective tissue mechanical receptors. This stimulation is transmitted by sensory nerves by means of spinal cord sympathetic ganglia and acts by releasing opioids such as encephalin in the spinal cord posterior nerve root, inhibiting pain transmission by thin fibers ${ }^{19}$.

\section{CONCLUSION}

Our findings indicate that Physiotherapy may be indicated to treat women with primary dysmenorrhea for being a low cost and noninvasive alternative. For such, there are several therapeutic resources, such as thermotherapy, cryotherapy, kinesiotherapy, TENS and connective tissue massage, acupuncture and Pilates, among others. Reviewed studies show satisfactory results of physiotherapeutic interventions, although the due methodological rigor is not always present, pointing to the need of further research in the area.

The number of publications on physiotherapeutic techniques is still small, so it is clear the need to develop quantitative, qualitative, randomized and controlled studies with higher methodological rigor with regard to physiotherapeutic maneuvers.

\section{REFERENCES}

1. Brown J, Brown S. Exercise for dysmenorrhoea. Obstet Gynecol. 2010;116(1):186-7.

2. Silva FC, Mukai LS, Vitalle MS. Prevalência de dismenorréia em pacientes avaliadas no centro de atendimento e apoio ao adolescente da Universidade Federal de São Paulo. Rev Paul Pediatr. 2004;22(2):85-8.

3. Rodrigues AC, Gala S, Neves A, Pinto Conceição, Meirelles C, Frutuoso C, et al. Dismenorreia em adolescentes e jovens adultas, Acta Med Port. 2011;24(2):383-92.

4. Barcelos PR, Conde DM, Deus JM, Martinez EZ. Qualidade de vida de mulheres com dor pélvica crônica: um estudo de corte transversal analítico. Rev Bras Ginecol Obstet. 2010;32(5):247-53

5. Motta EV, Salomão AJ, Ramos LO. Dismenorreia. Rev Bras Ginecol Obstet. 2000;57(5):369-86

6. Barbosa IC. Comparação da eficácia e segurança de valdecoxibe e piroxicam no tratamento da dismenorréia primária. Rev Bras Med. 2007;64(7):318-22.

7. Quintana LM, Heinz LN, Portes LA, Alfieri FM. Influência do nível de atividade física na dismenorreia. Rev Bras Ativ Física Saúde. 2010;15(2):101-4.

8. Diegoli MS, Diegoli CA, Fonseca AM. Dismenorréia. RBM. 2007;64(3):81-7.

9. Portal C, Honda S. Protocolo fisioterapêutico aplicado em mulheres que apresentam dismenorréia primária. Universidade da Amazônia. Centro de Ciências Biológicas e da Saúde. Belém; 2006. 1-61p. 
10. Fae AP, Hedioneia MF. Efeitos da massagem do tecido conjuntivo e cinesioterapia no tratamento da dismenorréia primária. Fisioter Brasil. 2010;11(2):1-2.

11. Kim JS, Jo YJ, Hwang SK. The effects of abdominal meridian massage on menstrual cramps and dysmenorrhea in full-time employed women. Taehan Kanho Hakhoe Chi. 2005;35(7):1325-32

12. Schiøtz HA, Jettestad M, Al-Heeti D. Treatment of dysmenorrhoea with a new TENS device (OVA). J Obstet Gynaecol. 2007;27(7):726-8.

13. Tugay N, Akbayrak T, Demirtürk F, Karakaya IC, Kocaacar O, Tugay U, et al. Effectiveness of transcutaneous electrical nerve stimulation and interferential current in primary dysmenorrhea. Pain Med. 2007;8(4):295-300.

14. Guo A, Meng Q. Acupuncture combined with spinal tui na for treatment of primary dysmenorrhea in 30 cases. J Tradit Chin Med. 2008;28(1):7-9.

15. Witt CL, Reinhold T, Brinkhaus B, Roll S, Jena S, Willich SN. Acupuncture in patients with dysmenorrhea: a randomized study on clinical effectiveness and cost-effectiveness in usual care. Am J Obstet Gynecol. 2008;198(2):166.e1-166.e8.

16. Araújo IM, Leităo TC, Ventura PL. Estudo comparativo da eficiência do calor e frio no tratamento da dismenorreia primária. Rev Dor. 2010;11(3):218-21.

17. Bazarganipour F, Lamyian M, Heshmat R, Abadi MA, Taghavi A. A randomized clinical trial of the efficacy of applying a simple acupressure protocol to the Taichong point in relieving dysmenorrhea. Int J Gynaecol Obstet. 2010;111(2):105-9.

18. Lin JA, Wong CS, Lee MS, Ko SC, Chan SM, Chen JJ, Chen TL. Successful treatment of primary dysmenorrhea by collateral meridian acupressure therapy. J Manipulative Physiol Ther. 2010;33(1):70-5.

19. Reis CA, Hardy E, Sousa MH. Efetividade da massagem do tecido conjuntivo no tratamento da dismenorréia primária em mulheres jovens. Rev Bras Saude Mater Infant. 2010;10(2):247-56.

20. Yu YP, Ma LX, Ma YX, Ma YX, Liu YQ, Liu CZ, et al. Immediate effect of acupuncture at Sanyinjiao (SP6) and Xuanzhong (GB39) on uterine arterial blood flow in primary dysmenorrhea. J Altern Complement Med. 2010;16(10):1073-8.

21. Liu CZ, Xie JP, Wang LP, Zheng YY, Ma ZB, Yang H, et al. Immediate analgesia effect of single point acupuncture in primary dysmenorrhea: a randomized controlled trial. Pain Med. 2011;12(2):300-7.
22. Mirbagher-Ajorpaz N, Adib-Hajbaghery M, Mosaebi F. The effects of acupressure on primary dysmenorrhea: a randomized controlled trial. Complement Ther Clin Pract. 2011;17(1):33-6.

23. Araújo LM, Silva JM, Bastos WT, Ventura PL. Diminuição da dor em mulheres com dismenorreia primária, tratadas pelo método Pilates. Rev Dor. 2012;13(2):119-23.

24. Nascimento MS. Efeito terapêutico da dança do ventre em mulheres com queixas sugestivas de dismenorreia primária. Nova Fisio. 2012;15(87).

25. Yeh ML, Hung YL, Chen HH, Wang YJ. Auricular acupressure for pain relief in adolescents with dysmenorrhea: a placebo-controlled study. J Altern Complement Med. 2013;19(4):313-8

26. Doty E, Attaran M. Managing primary dysmenorrhea. J Pediatr Adolesc Gynecol. 2006;19(5):341-4

27. Proctor M, Farquhar C. Diagnosis and management of dysmenorrhoea. BMJ. 2006;332(7550):1134-8.

28. Brito SA, Marques CC, Alves DS, Alexandre AC. Prevalence of dysmenorrhea in undergraduate health courses at an institution of higher education. Rev Enferm UFPE on line. $2012 ; 6(6): 1386-94$

29. Giraldo IP, Eleutério Júnior J, Linhares IM. Como diagnosticar e tratar dismenorréia. Rev Bras Med. Ed. Moreira Jr 2006;6:164-8.

30. Yáńez, N, Bautista RS, Ruiz SJ, Ruiz AM. Prevalencia y factores asociados a dismenorrea en estudiantes de ciencias de la salud. Rev Cienc Salud. 2010;8(3):37-48.

31. Gladwell V, Head S, Haggar M. Does a program of Pilates improve chronic non-specific low-back pain? J Sport Rehabil. 2006;15:338-50.

32. Schulz AP, Chao BC, Gazola F, Pereira GD, Nakanishi KM, Kunz RI, et al. Açấo da estimulaçăo elétrica nervosa transcutânea sobre o limiar de dor induzido por pressăo. Rev Dor. 2011;12(3):231-4.

33. Walsh DM, Howe TE, Johnson MI, Sluka KA. Transcutaneous electrical nerve stimulation for acute pain. Cochrane Database Syst Rev. 2009;15(2)CD006142.

34. Oliveira RG, Silva JC, Almeida AF, Araújo RC, Pitangui AC. TENS de alta e baixa frequência para dismenorreia primária: estudo preliminar. Conscientiae Saúde. 2012;11(1):149-58. 